\title{
A Coastal Resilience Analysis of a Heterogeneous Landscape
}

\author{
Robert Mendelsohn, Andry Rajaoberison, Jonghyun Yoo
}

Yale School of the Environment, New Haven, CT, USA

Email: robert.mendelsohn@yale.edu

How to cite this paper: Mendelsohn, R., Rajaoberison, A. and Yoo, J. (2020) A Coastal Resilience Analysis of a Heterogeneous Landscape. Journal of Environmental Protection, 11, 441-456.

https://doi.org/10.4236/jep.2020.116026

Received: April 28, 2020

Accepted: June 9, 2020

Published: June 12, 2020

Copyright $\odot 2020$ by author(s) and Scientific Research Publishing Inc. This work is licensed under the Creative Commons Attribution International License (CC BY 4.0).

http://creativecommons.org/licenses/by/4.0/

\begin{abstract}
This paper develops a fine-scaled analysis in order to determine the cost and benefit of flood protection using hardened coastal structures within a large coastal segment. The probability distribution of surges and the relative rate of sea level rise are estimated from local tidal data and combined with detailed GIS data of all buildings to compute flood damage. Examining a heterogeneous suburban coastline of $110 \mathrm{~km}$ length (Branford, Connecticut), the paper defines a complete set of small segments along the coast between high elevation points. For each segment, the study determines whether the benefit of seawalls exceeds the cost and the optimal height for each wall. The analysis compares a uniform wall across the entire town, a uniform wall across only the low lying parts of the coastline, and a unique wall in each micro segment that maximizes net benefits. The uniform wall across the entire town fails a benefit cost analysis. By simply restricting the wall to the $30 \%$ of the coastline that is low lying, the flood benefits begin to exceed the cost of the walls. By carefully identifying just the low lying segments where the benefit exceeds the cost, the overall benefit to cost ratio can be increased to 3 to 1 . The optimal flood protection program builds walls along only $10 \%$ of the coastline. These optimal micro segments are dispersed throughout the entire town including inland along a coastal river. The optimal elevation of the top of the walls is 2.3 $\mathrm{m}$ which is well below the $1 / 100$ year storm height of $3.2 \mathrm{~m}$. The benefit versus cost does not justify protection against rare but locally catastrophic storms such as hurricanes. Sea level rise increases the benefits of protection but plays only a small role in current protection decisions.
\end{abstract}

\section{Keywords}

Efficient Coastal Defense, Sea Level Rise, Storms, Geographic Scale

\section{Introduction}

It is well known that climate change will cause sea levels and storm intensities to 
rise over time leading to ever increasing potential flood damage to coastal communities [1]. The early literature on coastal defense tended to ignore storms and focused just on sea level rise. The very first studies to examine coastal protection against sea level rise explored where and when it was efficient to build walls to prevent flooding [2]-[7]. These studies suggested coastal defense should gradually be built as the seas rose to largely protect developed coastlines (cities) but not less developed coastlines. The most recent literature includes storms in their analysis of sea level rise and shows that the storm damage from a 1/100 year storm can substantially increase the damage caused by sea level rise alone [8] [9] [10]. The findings of this most recent literature support the earlier findings of protecting developed coastline with hardened structures but retreating along the less developed coastline of the world.

A general concern with all the studies that have looked at extensive coastlines of either a large country or the world is that these studies rely on large coastal segments $(70 \mathrm{~km})[11]$ that are assumed to be homogeneous. Although there are detailed site specific studies [3] [6] [7] [9], they tend to examine a very small sample of homogeneous sites. There is scant advice for a local town, county, or city explaining what to protect and where simply to retreat. This analysis addresses this local question to understand what exactly should be done at the local scale. What seawalls should be built in the near term given the rate of sea level rise and storm risk over the lifetime of the coastal defense investment? The analysis takes advantage of recently available data that permit spatially detailed analysis that provides sufficient detail for local towns (or counties) to identify where and where not to build walls in the near term.

This study begins with a basic theoretical model that maximizes the expected net benefit of coastal protection. The benefit of the wall is the reduced expected flood damage and the cost is the construction and maintenance cost of the seawall. The study uses the $110 \mathrm{~km}$ length of the Branford Connecticut as a case study because it is both a physically and economically heterogeneous suburban case study. The study first identifies the many small scale coastal segments that lie within this $110 \mathrm{~km}$ space. It then evaluates building a wall in each coastal segment to protect the buildings and infrastructure in that segment. The economic analysis compares the cost and benefit of treating the entire segment as a single block versus carefully defining and analyzing each small segment within the block.

The study finds that the cost of protecting the entire coastline of Branford with one $110 \mathrm{~km}$ wall exceeds the benefit. Limiting the wall just to the low lying segments of Branford just breaks even with the costs equal to the flood benefits achieved. However, carefully defining which segments to protect so that only net beneficial segments are protected, increases the benefit to cost ratio to 3 to 1 . The analysis suggests that it is now feasible to do spatially detailed analyses of coastal defense and that there is a large benefit to just building the seawalls that are needed. 


\section{Methodology}

\subsection{Theory}

The basic theory behind building a defensive coastal wall is to maximize its net benefits: Benefit, $B(H+E)$, minus Cost, $C(H)$ :

$$
\max _{H} B(H+E)-C(H)
$$

where $H$ is the height of the wall and $E$ is the elevation of the land upon which the wall is built. Although the methodology calculates the effectiveness of walls of various heights, this paper focuses on the wall height that maximizes net benefits. We do compare this optimal wall height versus another commonly proposed scheme which is to protect against the $1 / 100$ year storm (e.g. [8]). We examine building walls at Mean High High Water (MHHW) so that the walls will be away from the normal wave action of the sea. This height has the added benefit that it will have limited impact on existing beaches and wetlands. Alternative locations for walls at higher elevations were not examined in this study though such alternatives are worth investigating in future analyses.

Flood damage depends on sea level rise and storm risk. To capture these effects, the benefit function must be expanded to measure expected flood damage over time. The analysis assumes that a wall whose top has an elevation, $H$, prevents the damage from all storm surges, $h, H \geq h$. The expected benefit of a wall of height $H$ is equal to the expected damage avoided by that wall:

$$
E[B(H)]=\int_{0}^{H} \pi_{t}(h)\left(\sum D_{i}\left(h-a_{i}\right) V_{i}\right) \mathrm{d} h
$$

The expected benefit is equal to the sum across the vulnerable buildings, $i$, of the probability $\pi_{t}(h)$ of each surge times the damage, $D_{i}$ that is prevented by the wall given that surge. $\pi_{t}(h)$ gradually changes over time as sea level rise increases $h$. The damage depends of the depth of the flooding at that building, which is the height of the surge, $h$, minus the elevation of the building, $a_{p}$ times the value of the building $V_{i}$. The value of the building is used in this analysis, not the value of the property, because the building is what is damaged by a surge. The property itself is not permanently inundated. In the near term, the value of the land lost from inundation (caused by sea level rise) is relatively unimportant compared to the flood damage to existing buildings. Note that the optimal wall does not prevent all flood damage. There will remain a finite probability of high surges that will overtop the wall.

\subsection{Empirical Model}

The empirical analysis begins by identifying all the parcels in Branford that might be flooded over the next century. Figure 1 provides a map of Branford identifying the 2961 parcels that could be flooded by storm surges up to the maximum of $5 \mathrm{~m}$. The parcels are color coded by elevation. For example, the red parcels below $2.5 \mathrm{~m}$ in elevation are particularly vulnerable to storms but the purple parcels up to $3.1 \mathrm{~m}$ in elevation are also heavily affected. Many of the 


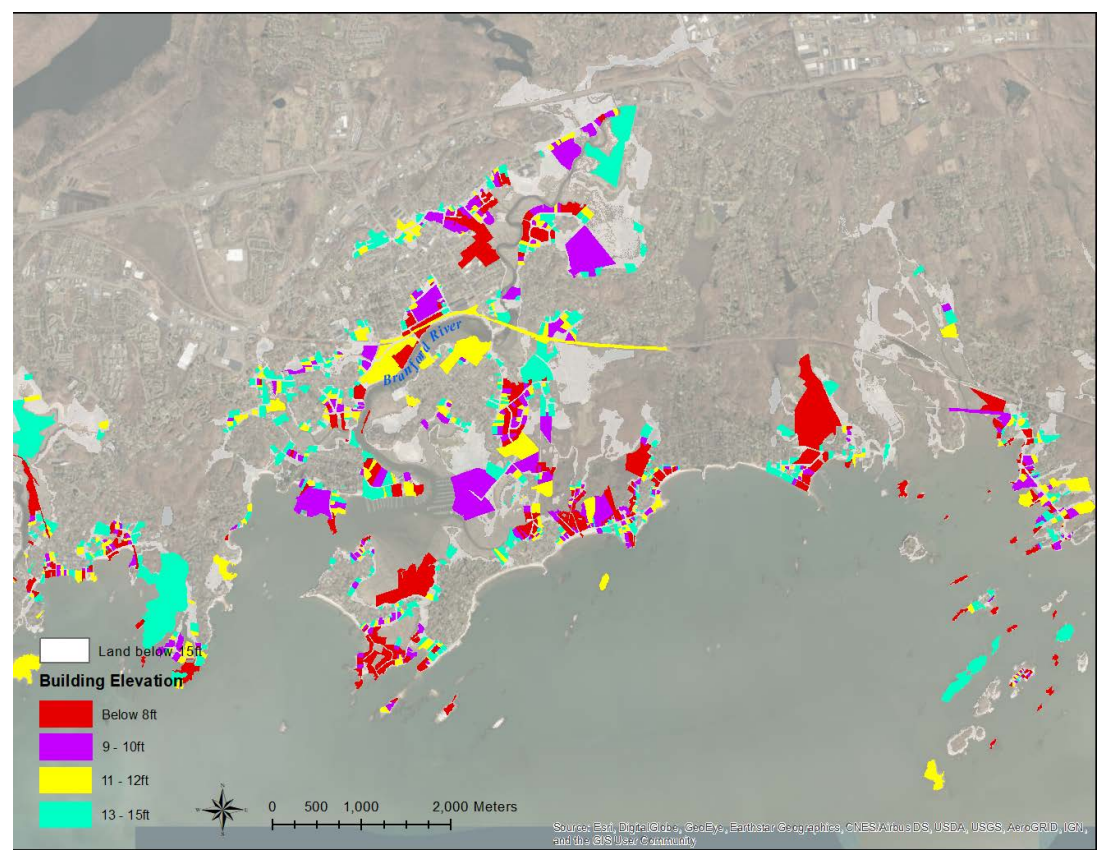

Figure 1. Elevation of vulnerable parcels in Branford CT. Source: Author calculation.

vulnerable properties lie along the coast but there are also properties along the inland rivers and wetlands that are vulnerable to coastal surge. The cumulative value of all the vulnerable buildings in Branford (below $5 \mathrm{~m}$ in elevation) is $\$ 694$ million. The analysis reveals that these vulnerable buildings are often located near the highest part of each parcel. The analysis is consequently based on the altitude of the land surrounding each building and not the average elevation of the parcel.

The empirical analysis next identifies all the spatially detailed coastal segments within Branford. A coastal segment is a contiguous low lying area between natural high points along the coast. The economic analysis eventually determines that the average optimal elevation of the top of the wall is about $2.5 \mathrm{~m}$ (8 feet). So the initial problem is to define all the low lying areas that lie between natural high points along the coast that are $2.5 \mathrm{~m}$ high.

The study relies on recent LIDAR data that carefully map the altitude of $2 \times 2$ foot pixels along the Connecticut coastline [12]. This data is sufficiently spatially detailed to identify every small coastal segment within Branford. A GIS program is developed that finds each of these coastal segments. This can be complicated in a heterogeneous landscape because some low lying coastal areas can be flooded from more than one direction (source) given nearby creeks and rivers. The GIS program identifies the length $(L)$ of each of these coastal segments at MHHW as well as the potential flooded area within each segment.

The analysis examines building a set of sea walls for each segment that vary in height. The study examines a range of top elevations from MHHW (zero height) to $5 \mathrm{~m}$ (maximum surge this century). The construction cost of the wall is proportional to the length $(L)$ of the wall. Because the wall is effectively a triangle 
with a wide base, the construction cost of the wall increases with the square of its height $(H)$ as first suggested by [2]:

$$
\text { Construction Cost }=A H^{2} L
$$

This study relies on an updated cost estimate of $A$ of $\$ 5200$ for a $1 \mathrm{~m}$ high hardened wall that is $1 \mathrm{~m}$ in length. The coastal wall is expected to last 30 years after which it will have to be replaced [13]. The maintenance cost over the lifetime of the wall is the present value of annual maintenance for 30 years. Annual maintenance is expected to be $0.5 \%$ of construction cost per year [13]. The interest rate used in this analysis is the current municipal bond rate, 2.5\% [14] which reflects the interest rate that local towns and counties would face to finance these projects. Given these assumptions, the present value of maintenance is equal to $11 \%$ of construction costs. The total cost is:

$$
C(H)=1.11 * 5200 H^{2} L
$$

The more difficult empirical step in the analysis is measuring the flood benefits of each wall. The benefit analysis begins by determining all the vulnerable buildings that lie within each coastal segment. The study takes advantage of a recent data set that gives precise locations of all buildings in the United States [15]. This information is combined with the LIDAR data to determine the elevation of the ground around each building. The building data from the Assessor's Office of the Town of Branford is then matched with the Microsoft data to get an estimate of the value of each building. The GIS program is therefore able to identify all the buildings in each coastal segment, their elevation, and their value.

In order to assess flood risks, the analysis needs an estimate of the relative rate of local sea level rise for the lifetime of the flood control project (30 years) [16]. Data from a nearby tidal station provide an estimate of the local rate of relative sea level rise (see Figure 2). This compares the rate at which the ocean is rising relative to the height of the land. It therefore takes into account both changes in the local sea level and changes in the local land as well. One interesting result in Figure 2 is that the nearby Long Island Sound has been rising at a constant relative rate of $3 \mathrm{~mm} / \mathrm{yr}$ for the last 50 years (the tidal record). A tidal station in nearby New York City shows that relative sea level rise has been constant since 1854 [17]. There is no evidence in the local record of the rate of sea level rise accelerating over time yet. We consequently assume that the best guess of sea level rise over the next 30 years is this observed rate of $3 \mathrm{~mm} / \mathrm{yr}$. Of course, climate models predict this rate will increase over time so we also examine a scenario where SLR is increased to $6 \mathrm{~mm} / \mathrm{yr}$ as the climate models predict by the end of the century [1].

NOAA [18] data measuring extreme annual tides are used to estimate the probability distribution of extreme tides. Every storm surge height, $h$, has an estimated frequency which is determined by the probability distribution of extreme tides, $\pi(h)$. The probability distribution of surge height is estimated using maximum annual tidal data from the Bridgeport station and a Generalized Extreme Value (GEV) function: 


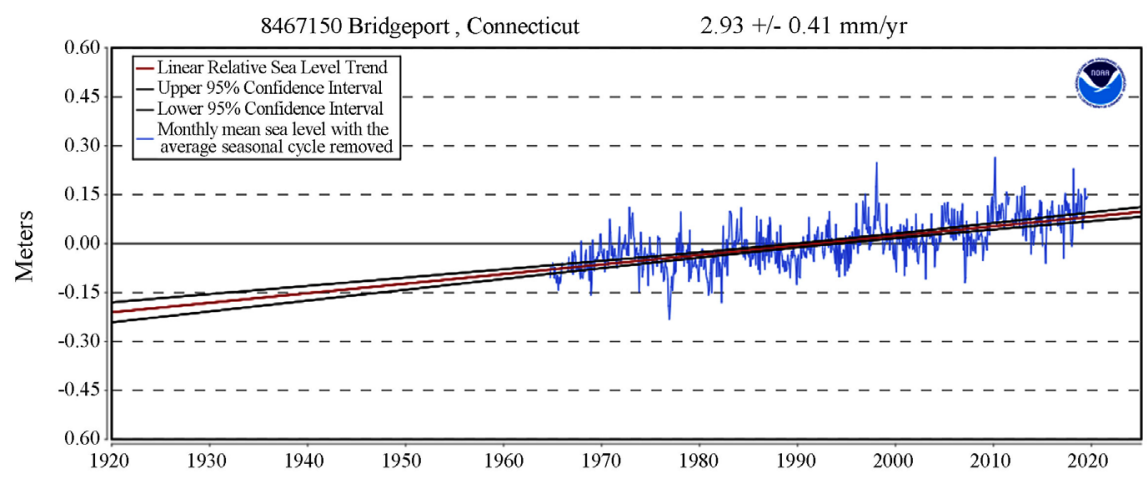

Figure 2. Relative sea level trend at bridgeport, CT. Source: [16].

$$
F(x: \mu, \sigma, k)=\exp \left\{-\left[1+k \frac{(x-\mu)}{\sigma}\right]^{-\frac{1}{k}}\right\}
$$

where $\mu$ is the location parameter (mean height), $\sigma$ is the scale parameter, and $k$ is the shape parameter. The estimated parameters from this model for Bridgeport are: $\mu=1.818, \sigma=0.147$, and $k=0.296$. Figure 3 presents the probability versus height of each potential storm surge from this estimated GEV function. The highest recorded surge in the Bridgeport tidal data was from Hurricane Sandy in 2012 which caused a storm surge of $2.9 \mathrm{~m}$. The $1 / 100$ year storm has a surge of $3.2 \mathrm{~m}$ and the $1 / 500$ year storm has a surge of $4.4 \mathrm{~m}$. Sea level rise effectively shifts the probability flooding function in Figure 3 to the right by the amount the sea rises each year [19].

We utilize a damage function from the HAZUS model [20] that calculates the damage to a building as a function of the depth of flooding at that building and the value of the building. The damage to buildings with a basement starts at zero at a flood depth of $-1 \mathrm{~m}$ relative to the ground ( 2 meters below the first floor elevation) and rises linearly to $100 \%$ when flood depth is $8 \mathrm{~m}$ above ground.

The aggregate damage to buildings in each coastal segment is the sum of the damages to all the buildings in that segment at each storm surge height. We double this damage to include damage to roads, utilities, and public facilities as well as costs of emergency services and clean up to the state and towns [21].

The analysis then calculates the present value of cost and expected flood benefit of each potential wall for each segment over the 30 year lifetime of the seawall. For each surge within the segment, the program estimates which buildings are flooded and the flood damage to that building. Summing across events weighted by their probability gives the expected flood damage of each building. Summing the expected damage across buildings gives the aggregate flood damage in that coastal segment. The benefit of the wall is the flood damage prevented. This is equal to all the flood damage that lies beneath the top of the wall. The additional benefit of higher walls is that they eliminate a little more flood damage. The cost is that they are a little more expensive to build and maintain. By examining a range of building elevations, the program shows the tradeoffs between cost and benefit. 


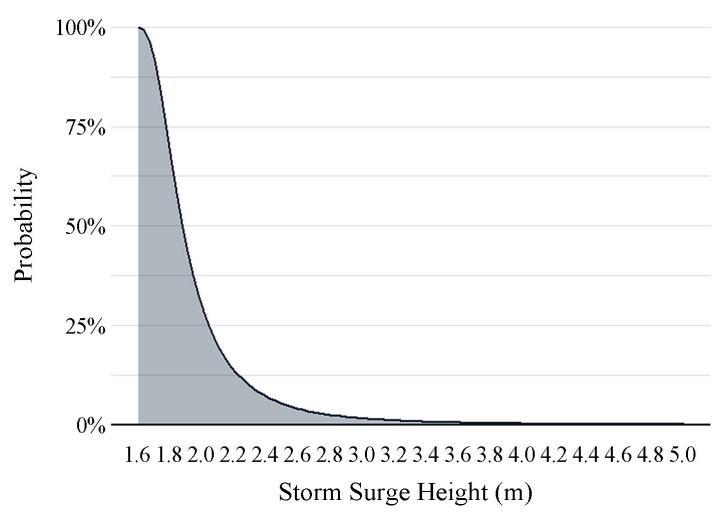

Figure 3. Probability of different storm surge heights. Source: Computed by authors from [18].

\section{Results}

We first use the above methodology to evaluate a uniform wall that would be built the $110 \mathrm{~km}$ length of Branford coastline at MHHW. The present value cost of this single wall is $\$ 635$ million and the present value of flood benefits over the next 30 years would be $\$ 279$ million. The cost of this single wall far exceeds the benefit and it should not be built.

However, the GIS analysis reveals that only $31 \mathrm{~km}$ of the $110 \mathrm{~km}$ length is low lying coastline. There is a great deal of relatively high land near the coast in Branford. Simply paying attention to the geographic variation within the town, we explore building walls only along lowland. The aggregate cost of the wall along just lowland coastline is $\$ 193$ million with benefits of $\$ 271$ million. There are very few benefits associated with building walls on high ground. Restricting walls to just low lying coastal land allows the aggregate coastal protection plan to pass a benefit cost test. Taking advantage of information about just coastal elevation within the segment helps improve the coastal defense plan dramatically in this case study.

The analysis then explores whether the spatially detailed economic data is also helpful. The micro scale analysis examines each low lying segment and evaluates whether or not to build a wall in each segment. The cost heavily depends on the length of the segment and the benefits depend on the aggregate expected flood damage within that segment. The flood benefits, in turn, depend on the number of vulnerable buildings, their value, and their elevation.

The flood damage is very sensitive to the elevation of each building. The federal rules for flood insurance make a large distinction between being inside or outside the 1/100 year flood plain which is an elevation of $3.2 \mathrm{~m}$ in Branford. But expected flood damage rises rapidly as the ground elevation of the building falls. For example, the present value of expected flood damage is $100 \%$ of the value of a building at $2.5 \mathrm{~m}$. It falls to $19 \%$ at an elevation of $3 \mathrm{~m}, 5 \%$ at $3.5 \mathrm{~m}, 1.6 \%$ at 4 $\mathrm{m}$, and $0.2 \%$ at $5 \mathrm{~m}$. The very low elevation buildings flood a lot. For example, the $2.5 \mathrm{~m}$ elevation building would expect to see 2 floods a year, whereas a building 
at $3 \mathrm{~m}$ would only see a flood every 3 years, and at a $3.5 \mathrm{~m}$ elevation, the building would see a flood every 20 years. Flood damage per building is a highly nonlinear function of elevation. Note that the 1/100 year storm in Branford leads to a $3.2 \mathrm{~m}$ surge which has an expected flood damage of $10 \%$. There is a lot of variation in expected storm damage within the 1/100 year floodplain and there is a lot of expected flood damage outside the 1/100 year floodplain. Flood benefits are very sensitive to accurate elevation data for buildings.

Whether a building has a basement is also critical along the coast. Buildings without basements are much less vulnerable to flooding. The present value of damage for a building with no basement at $2 \mathrm{~m}$ elevation is $1.5 \%$ of the value of the building, at $2.5 \mathrm{~m}$ it is just $0.6 \%$, and at $3 \mathrm{~m}$ it is just $0.2 \%$. Low elevation buildings should be strongly encouraged to have no basement.

In many segments, the cost of any wall exceeds the expected flood benefit. There are simply not enough low lying and valuable buildings in the segment to justify the wall. There are only 31 coastal segments in Branford where the benefit exceeds the wall costs as shown in Table 1 . These 31 segments account for only $10 \mathrm{~km}, 9 \%$ of the Branford coastline. Most of the segments are along the coast but a few segments are inland along the Branford River. The length of each wall is determined by the length of the low lying section. The height of the wall has been optimized for each location to maximize net benefits. The elevation at the top of the wall averages $2.4 \mathrm{~m}$. However, because the wall is built on land that is $1.1 \mathrm{~m}$ in elevation, the actual average wall height is $1.3 \mathrm{~m}$ (about $4.3 \mathrm{feet}$ ). Not all the segment walls are the same height. Some segments call for a slightly higher wall. For example, the wall at Sunrise Cove is almost $1.9 \mathrm{~m}$ high because there is more avoided flood damage here per length of wall.

Table 1. Cost and benefit of walls by coastal segment in Branford CT.

\begin{tabular}{|c|c|c|c|c|c|c|c|}
\hline Section & ID & $\begin{array}{l}\text { Wall } \\
\text { Length } \\
\mathrm{m}\end{array}$ & $\begin{array}{l}\text { Wall } \\
\text { Height } \\
\text { m }\end{array}$ & $\begin{array}{c}\text { PV of } \\
\text { Cost } \\
\text { (million USD) }\end{array}$ & $\begin{array}{c}\text { PV of } \\
\text { Benefit } \\
\text { (million USD) }\end{array}$ & $\begin{array}{c}\text { PV of } \\
\text { Net Benefit } \\
\text { (million USD) }\end{array}$ & $B / C$ \\
\hline All MICRO & & & 1.31 & 98.6 & 327.0 & 228.4 & 3.12 \\
\hline Short Beach Johnson's Beach & 50 & 288 & 1.22 & 2.47 & 6.68 & 4.20 & 2.70 \\
\hline $\begin{array}{l}\text { Short Beach } \\
\text { Beckett Ave }\end{array}$ & 52 & 149 & 1.54 & 2.04 & 10.22 & 8.18 & 5.01 \\
\hline $\begin{array}{l}\text { Short Beach } \\
\text { Stanley Point }\end{array}$ & 54 & 144 & 1.18 & 1.16 & 2.32 & 1.16 & 2.00 \\
\hline $\begin{array}{l}\text { Short Beach } \\
\text { Sunrise Cove }\end{array}$ & 67 & 130 & 1.86 & 2.60 & 15.70 & 13.11 & 6.05 \\
\hline $\begin{array}{c}\text { Short Beach } \\
\text { Lamphier Cove }\end{array}$ & 71 & 58 & 1.44 & 0.69 & 3.75 & 3.05 & 5.40 \\
\hline $\begin{array}{l}\text { Short Beach } \\
\text { Pages Cove }\end{array}$ & 89 & 342 & 1.34 & 3.54 & 12.27 & 8.72 & 3.46 \\
\hline $\begin{array}{c}\text { Indian Neck } \\
\text { Haycock Point }\end{array}$ & 85 & 258 & 1.28 & 2.07 & 3.75 & 1.68 & 1.81 \\
\hline
\end{tabular}




\section{Continued}

\begin{tabular}{|c|c|c|c|c|c|c|c|}
\hline $\begin{array}{l}\text { Indian Neck } \\
\text { Linden Ave }\end{array}$ & 90 & 222 & 1.28 & 1.78 & 3.93 & 2.14 & 2.20 \\
\hline $\begin{array}{l}\text { Indian Neck } \\
\text { Wilford Road }\end{array}$ & 93 & 584 & 1.42 & 6.05 & 25.33 & 19.28 & 4.19 \\
\hline $\begin{array}{c}\text { Indian Neck } \\
\text { Sybil Creek Bridge Rt } 146\end{array}$ & 99 & 275 & 1.22 & 1.59 & 1.85 & 0.26 & 1.16 \\
\hline $\begin{array}{l}\text { Indian Neck } \\
\text { Crouch Rd }\end{array}$ & 102 & 235 & 1.20 & 3.13 & 8.87 & 5.74 & 2.83 \\
\hline $\begin{array}{l}\text { Indian Neck } \\
\text { Rice Rd }\end{array}$ & 103 & 253 & 1.34 & 2.47 & 6.77 & 4.30 & 2.74 \\
\hline $\begin{array}{c}\text { Indian Neck } \\
\text { Waverly Park Rd }\end{array}$ & 122 & 355 & 1.32 & 2.95 & 7.69 & 4.74 & 2.61 \\
\hline $\begin{array}{l}\text { Indian Neck } \\
\text { 7th Ave }\end{array}$ & 128 & 163 & 1.24 & 1.45 & 4.92 & 3.48 & 3.40 \\
\hline $\begin{array}{l}\text { Indian Neck } \\
\text { Seaview Ave }\end{array}$ & 138 & 189 & 1.52 & 2.79 & 18.90 & 16.11 & 6.77 \\
\hline $\begin{array}{l}\text { Indian Neck } \\
\text { Tabor Drive }\end{array}$ & 220 & 531 & 1.34 & 4.71 & 10.66 & 5.94 & 2.26 \\
\hline $\begin{array}{l}\text { Pawson Park } \\
\text { Linden Point }\end{array}$ & 15 & 272 & 1.34 & 2.49 & 7.49 & 5.00 & 3.01 \\
\hline $\begin{array}{l}\text { Pawson Park } \\
\text { Bayberry Ln }\end{array}$ & 19 & 82 & 1.20 & 0.70 & 1.56 & 0.85 & 2.21 \\
\hline $\begin{array}{l}\text { Pawson Park } \\
\text { South }\end{array}$ & 29 & 1,712 & 1.28 & 16.19 & 53.37 & 37.18 & 3.30 \\
\hline $\begin{array}{l}\text { Lower Branford } \mathrm{R} \\
\text { Branford Landing }\end{array}$ & 397 & 1,012 & 1.22 & 8.69 & 20.83 & 12.14 & 2.40 \\
\hline $\begin{array}{l}\text { Upper Branford R } \\
\text { Aceto Street }\end{array}$ & 295 & 844 & 1.44 & 10.10 & 41.93 & 31.83 & 4.15 \\
\hline $\begin{array}{l}\text { Upper Branford R } \\
\text { Willow Road }\end{array}$ & 296 & 291 & 1.10 & 2.03 & 3.75 & 1.72 & 1.84 \\
\hline $\begin{array}{l}\text { Upper Branford R } \\
\text { Pine Orchard Rd }\end{array}$ & 238 & 123 & 1.64 & 2.14 & 3.70 & 1.53 & 2.26 \\
\hline $\begin{array}{l}\text { Pine Orchard } \\
\text { Brown Point }\end{array}$ & 136 & 379 & 1.44 & 4.54 & 20.99 & 16.45 & 4.63 \\
\hline $\begin{array}{c}\text { Pine Orchard } \\
\text { Pine Orchard Club }\end{array}$ & 217 & 258 & 1.44 & 3.09 & 14.07 & 10.98 & 4.55 \\
\hline $\begin{array}{c}\text { Stony Creek } \\
\text { Linden Point to Long Point }\end{array}$ & 107 & 118 & 1.28 & 1.12 & 3.11 & 1.99 & 2.78 \\
\hline $\begin{array}{l}\text { Stony Creek } \\
\text { Linden Point }\end{array}$ & 113 & 241 & 1.16 & 1.87 & 4.29 & 2.42 & 2.29 \\
\hline $\begin{array}{l}\text { Stony Creek } \\
\text { Village-Dock }\end{array}$ & 172 & 433 & 1.08 & 2.92 & 4.71 & 1.79 & 1.62 \\
\hline $\begin{array}{l}\text { Stony Creek } \\
\text { Squaw Brook }\end{array}$ & 180 & 102 & 1.18 & 0.82 & 2.16 & 1.34 & 2.63 \\
\hline $\begin{array}{c}\text { Stony Creek } \\
\text { End Thimble Island Rd }\end{array}$ & 112 & 100 & 1.18 & 0.88 & 1.39 & 0.51 & 2.25 \\
\hline
\end{tabular}


The 31 walls identified by the micro spatial analysis cost a total of $\$ 99$ million to build and yield expected benefits of $\$ 327$ million. The micro walls cost less than the uniform wall because they are only being built along one fourth of the coastal lowland. Taller walls are justified because there are more flood benefits in these selected segments. The overall benefit cost ratio with the micro walls is 3.2. Coastal defense is a lot more effective when only walls with a positive net benefit are proposed.

Detailed spatial analysis can also set priorities concerning which wall to build first. The higher $B / C$ in Sunrise Cove, Beckett Avenue, Lamphier Cove, and Seaview Avenue make these attractive projects to start with. It is also likely that having multiple possible projects will help towns move forward. If some local neighborhoods initially balk at coastal protection, the town can move on other projects and demonstrate that these walls are worthwhile.

A map has been created for each of the seven sections in Table 1. The maps for Short Beach and Indian Neck are shown in Figure 4(a) and Figure 4(b) respectively. The remaining maps for the rest of Branford are in Figures A1-A5. The maps as a whole identify every coastal segment in Table 1. The GIS program draws in blue where each wall is placed. The land that is protected by each wall is colored in behind. Vulnerable buildings are identified in green in the map so that one can see which vulnerable buildings are protected by each wall. Most segments can be protected by a single continuous wall. However, there are three segments in Figure 4 that need two walls to protect the segment. Johnsons Beach (50) needs a wall east and west of the segment, and both Tabor Drive (220) and Wilford Road (93) need a wall south and north to protect from flooding from the coast and the Branford River, respectively.

Another advantage of the segment analysis is that the resulting plan identifies exactly where to ask engineers to make final building plans. Engineers would still have to make site visits and check detailed specifications to make sure that the proposed wall does not face any hidden constraints. Site details such as bedrock, sloping land, existing buildings, utilities, roads, and streams would all have to be taken into account in the engineering plan.

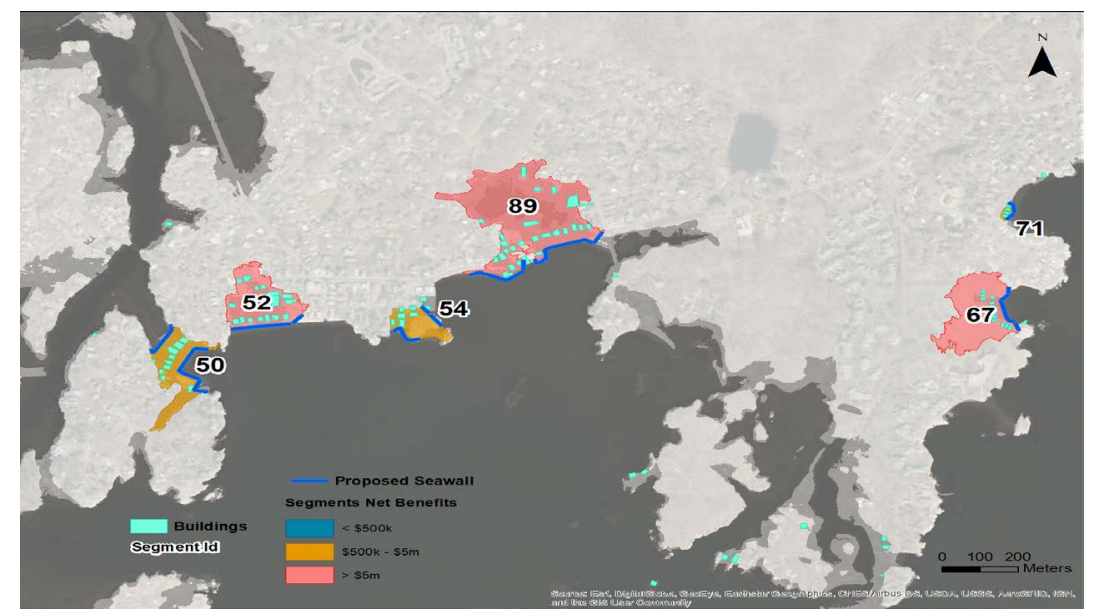

(a) 


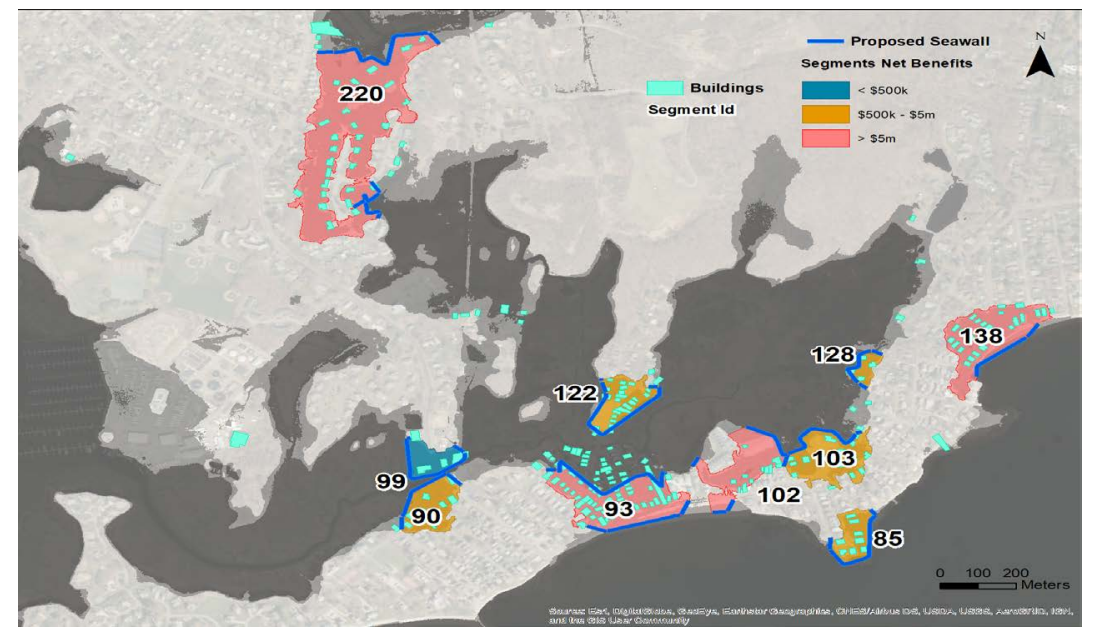

(b)

Figure 4. (a) Short Beach protected segments; (b) Indian Neck protected segments. Source: Author calculation.

\section{Conclusions}

This paper evaluates protecting all the coastal segments in Branford CT along its $110 \mathrm{~km}$ of coastline. There are about 2961 parcels in Branford that are vulnerable to storm surge and the buildings on these parcels are worth about $\$ 694$ million. This study examines whether the benefit of building a coastal wall to protect Branford is greater than the cost. The analysis examines three alternative plans. One plan builds a uniform wall across the entire coastline of Branford. A second plan builds a uniform wall only along low lying coastline within Branford. The third plan evaluates each possible coastal segment and only builds walls when the benefit exceeds the cost. The paper is trying to determine the value of incorporating spatial detail into coastal defense plans. The experiment is performed on only a single town in Connecticut so that it is merely suggestive. But the paper proves one can do fine scale analysis of coastal defense and that such analyses can be quite valuable.

The study finds that if one ignores all the variation within Branford, no wall should be built to protect this town. The cost far exceeds the benefit. However, just paying attention to geographic detail and building a wall only along the 31 $\mathrm{km}$ of low elevation coastline, the benefit of the wall (\$271 million) exceeds the cost (\$191 million). However, many of these low lying segments would still not individually pass an economic benefit cost test. Limiting walls only to segments where the benefit exceeds the cost reveals there are 31 small segments accounting for just $10 \mathrm{~km}$ of the $31 \mathrm{~km}$ of low lying coastline where a wall is justified. By carefully targeting walls just to these desirable segments, the overall cost of the walls falls by half to $\$ 98$ million and the overall benefit slightly increases to $\$ 326$ million. The higher benefit comes from the higher walls that can be justified at these high damage locations. Spatially detailed analysis can increase the benefit cost ratio of coastal defense substantially by concentrating expenditures where 
they will do the most good.

Study finds the average optimal elevation for the top of these walls is about 2.3 $\mathrm{m}$ although this varies from 2.1 to $2.9 \mathrm{~m}$ across segments. The height of these walls is well below what would stop a 1/100 year storm which is $3.2 \mathrm{~m}$ in Branford. The expected additional flood benefit from the $3.2 \mathrm{~m}$ wall is far outweighed by the additional cost. High surges lead to more damage but they simply do not happen frequently enough to justify taller walls. The rule of thumb to protect against the $1 / 100$ year storm is not economically justified in Branford.

The fact that the walls do not protect against all risks, however, should be addressed. There is a need to complement the walls with actuarially fair flood insurance for rare storms. The wall will protect against common storms and the insurance against rare storms. The cost of the insurance which is equal to the expected remaining flood damage is less than the cost of building ever taller walls. Because the walls have eliminated the bulk of the expected damage, the cost of this insurance should be relatively low behind these walls. However, the walls do not protect every vulnerable resident. There are many vulnerable properties that cannot be effectively protected by walls. The cost of the walls is simply too high relative to the benefit along most of the coastline.

The analysis also examines the effect of a much faster rate of SLR, averaging 6 $\mathrm{mm} / \mathrm{yr}$ instead of the $3 \mathrm{~mm} / \mathrm{yr}$ that has been observed over the last 50 years. The faster rate of SLR increases the benefits from building walls by $10 \%$. This helps the benefit to cost ratio slightly and leads to slightly higher walls but it does not really change the optimal decision. The result reveals SLR does not play a large role in whether or not to protect the coastline today. However, SLR can play a significant role later in the century when the seas are substantially higher.

This analysis assesses coastal adaptation that makes sense for Branford to do immediately. With climate change, the optimal coastal defense in the future may change. Future coastal development may also increase what is at risk in the future. The analysis done in this study should be reassessed every decade or two to see if new walls need to be built and to eventually replace existing walls as they deteriorate.

This analysis does not address every coastal concern. The analysis does not address concerns about erosion control, wetland management, marine resources, wind damage, and risks from fresh water flooding. The question of who should pay for coastal defense is not addressed. Finally, there are important concerns about how to design a wall. The wall could be built from stone or cement or have ivy and plantings. It could be incorporated into open space landscapes. It could be part of roads and railways. Such design details may well determine the public acceptance of any proposed wall and its effectiveness.

\section{Conflicts of Interest}

The authors declare no conflicts of interest regarding the publication of this paper. 


\section{References}

[1] IPCC (Intergovernmental Panel on Climate Change) (2014) Climate Change 2014 Synthesis Report, Fifth Assessment Report.

https://doi.org/10.1017/CBO9781107415416

[2] Yohe, G.W., Neumann, J.E. and Ameden, H. (1995) Assessing the Economic Cost of Greenhouse-Induced Sea Level Rise Methods and Application in Support of a National Survey. Journal of Environmental Economics Management, 29, 78-97. https://doi.org/10.1006/jeem.1995.1062

[3] Yohe, G.W., Neumann, J.E., Marshall, P. and Ameden, H. (1996) The Economic Cost of Greenhouse-Induced Sea-Level Rise for Developed Property in the United States. Climatic Change, 32, 387-410. https://doi.org/10.1007/BF00140353

[4] Bosello, F., Roson, R. and Tol, R.S.J. (2007) Economy-Wide Estimates of the Implications of Climate Change: Sea Level Rise. Environmental and Resource Economics, 37, 549-571. https://doi.org/10.1007/s10640-006-9048-5

[5] Anthoff, D., Nicholls, R.J. and Tol, R.S.J. (2010) The Economic Impact of Substantial Sea-Level Rise. Mitigation Adaptation Strategies Global Change, 15, 321-335. https://doi.org/10.1007/s11027-010-9220-7

[6] Neumann, J.E., Hudgens, D.E., Herter, J. and Martinich, J. (2010) Assessing Sea-Level Rise Impacts: A GIS-Based Framework and Application to Coastal New Jersey. Coastal Management, 38, 433-455. https://doi.org/10.1080/08920753.2010.496105

[7] Neumann, J.E., Hudgens, D.E., Herter, J. and Martinich, J. (2010) The Economics of Adaptation along Developed Coastlines. Climatic Change, 2, 89-98.

https://doi.org/10.1002/wcc.90

[8] Nicholls, R.S., Hanson, S., Herweijer, C., Patmore, N., Hallegatte, S., Corfee-Morlot, J., Château, J. and Muir-Wood, R. (2008) Ranking Port Cities with High Exposure and Vulnerability to Climate Extremes. OECD Environment Working Papers No. 1, OECD Publishing, Paris.

[9] Neumann, J.E., Emanuel, K., Ravela, S., Ludwig, L., Kirshen, P., Bosma, K. and Martinich, J. (2015) Joint Effects of Storm Surge and Sea-Level Rise on US Coasts: New Economic Estimates of Impacts, Adaptation, and Benefits of Mitigation Policy. Climatic Change, 129, 337-349. https://doi.org/10.1007/s10584-014-1304-Z

[10] Diaz, D. (2016) Estimating Global Damages from Sea Level Rise with the Coastal Impact and Adaptation Model (CIAM). Climatic Change, 137, 143-156. https://doi.org/10.1007/s10584-016-1675-4

[11] Vafeidis, A.T., Nicholls, R.J., McFadden, L., Tol, R.S.J., Hinkel, J., Spencer, T., Grashoff, P.S., Boot, G. and Klein, R.J.T. (2008) A New Global Coastal Database for Impact and Vulnerability Analysis to Sea-Level Rise. Journal of Coastal Research, 24, 917-924. https://doi.org/10.2112/06-0725.1

[12] Capitol Region Council of Governments (2016) 2016 Lidar DEM. http://cteco.uconn.edu/data/flight2016/index.htm

[13] Aerts, J.C. (2018) A Review of Cost Estimates for Flood Adaptation. Water, 10, 1646. https://doi.org/10.3390/w10111646

[14] United States Treasury Department (2019) Daily Treasury Long Term Rate Data. https://www.treasury.gov/resource-center/data-chart-center/interest-rates/pages/tex tview.aspx?data=longtermrate

[15] Microsoft (2018) Microsoft Building Footprints. https://github.com/microsoft/USBuildingFootprints

[16] NOAA (National Oceanic and Atmospheric Administration) (2019) Relative Sea 
Level Trend.

https://tidesandcurrents.noaa.gov/sltrends/sltrends_station.shtml?id=8467150

[17] Zervas, C. (2009) Sea Level Variations of the United States: 1854-2006. NOAA Technical Report NOS CO-OPS 053.

https://tidesandcurrents.noaa.gov/publications/Tech_rpt_53.pdf

[18] NOAA (National Oceanic and Atmospheric Administration) (2019) Monthly Maximum Tides. https://tidesandcurrents.noaa.gov/reports.html?id=8467150

[19] Tebaldi, C., Strauss, B. and Zervas, C. (2012) Modelling Sea-Level Rise Impacts on Storm Surges along US Coasts. Environmental Research Letters, 7, Article ID: 014032. https://doi.org/10.1088/1748-9326/7/1/014032

[20] United States Department of Homeland Security (FEMA) (2019) Multi-Hazard Loss Estimation Methodology Flood Model. Federal Emergency Management Agency, Washington DC. https://www.fema.gov/hazus-mh-flood-model

[21] de Moel, H., Botsen, W. and Aerts, J. (2013) Economic and Direct Losses from Hurricane Sandy. Annals New York Academy Sciences, 1294, 80-89. 


\section{Online Appendix: “A Coastal Resilience Analysis of a Heterogeneous Landscape"}

The following figures are maps of the Upper Branford River, Lower Branford River Pawson Park, Pine Orchard and Stony Creek segments of Branford listed in Table 1. Each map identifies the optimal wall to be built for each coastal segment as shown in blue and the area in pink and orange that would be protected. Vulnerable buildings are also shown in green on the map, some of which are not protected by any wall. The numbers identify each segment in Table 1 .

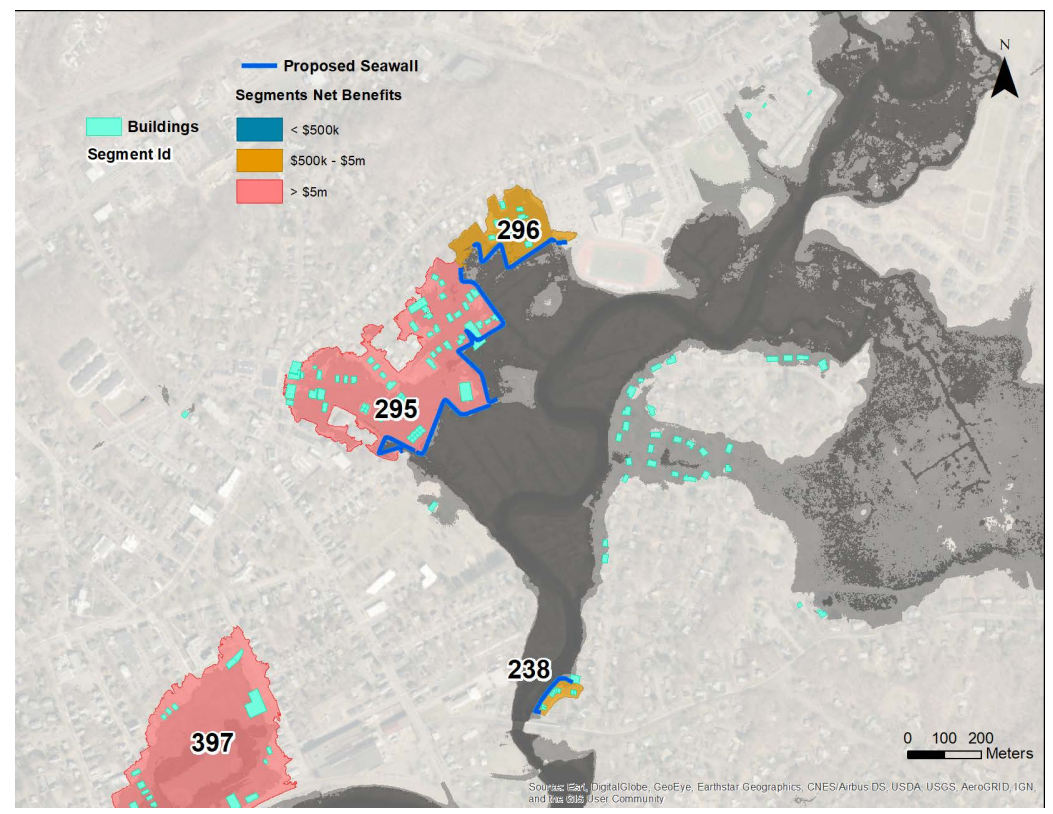

Figure A1. Upper Branford River protected segments. Source: Author calculation.

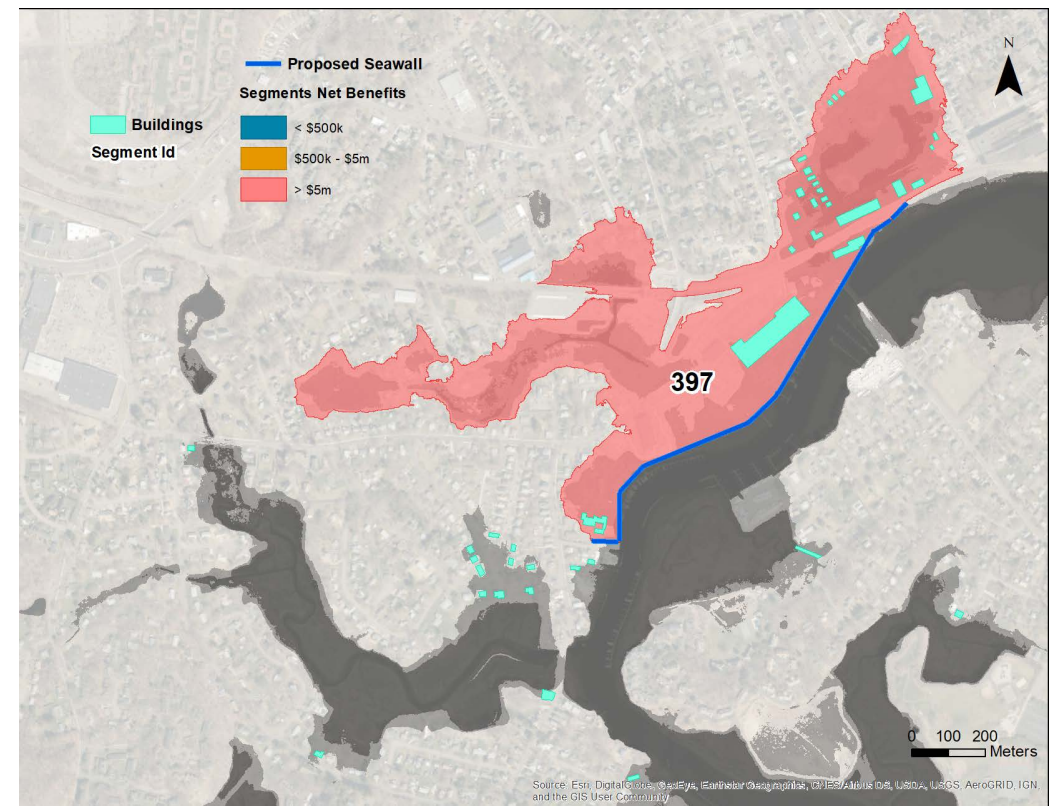

Figure A2. Lower Branford River protected segments. Source: Author calculation. 


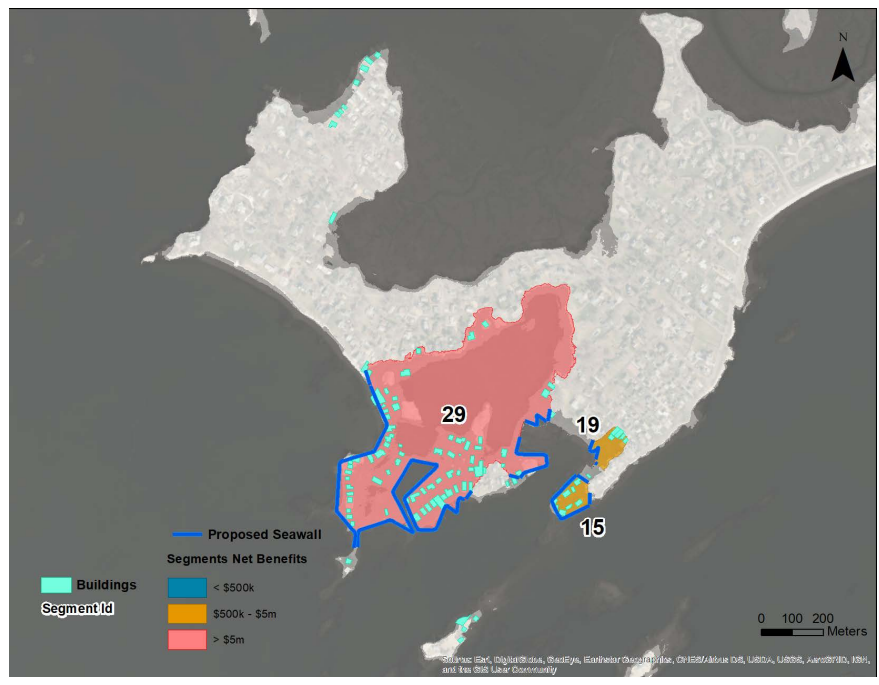

Figure A3. Pawson Park protected segments. Source: Author calculation.

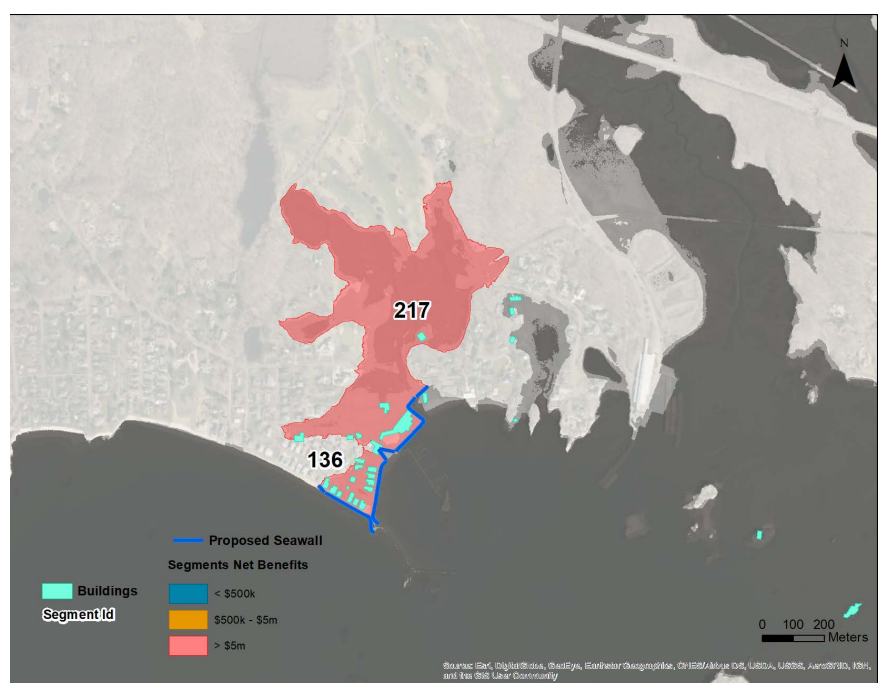

Figure A4. Pine Orchard protected segments. Source: Author calculation.

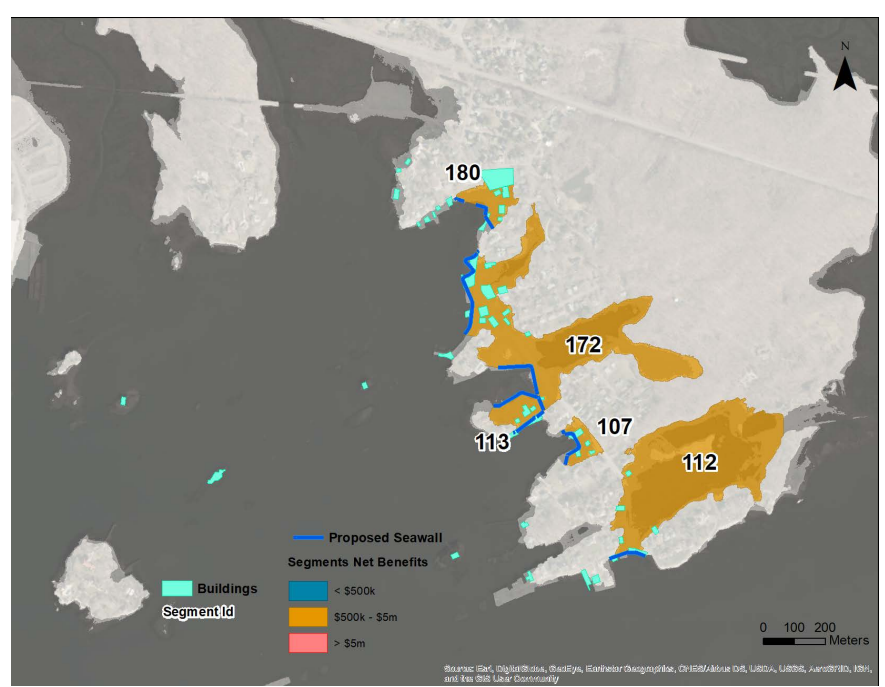

Figure A5. Stony Creek protected segments. Source: Author calculation. 